\title{
ANALISIS MOTIVASI DAN GAYA BELAJAR SISWA DALAM PEMBELAJARAN DI SEKOLAH DASAR
}

\author{
I Nyoman Jampel \\ Jurusan Teknologi Pendidikan, Fakultas Ilmu Pendidikan \\ Universitas Pendidikan Ganesha, Singaraja, Bali \\ Email: nyoman.jampel@gmail.com
}

\begin{abstract}
This study aimed to describe the student's learning style and students' motivation in class V SD Cluster VI Abang District Karangasem regency. This research is a qualitative descriptive study. Namely research samples fifth grade students of elementary schools in Cluster VI Abang District Karangasem year 2015/2016 subject is SDN 1 Pidpid, SDN 1 Nawa Kerti, and SDN 1 Kesimpar which amounted to 51 people. Methods of data collection used the questionnaires, observation, interviews and documentation. Data collected were analyzed using descriptive analysis. The results of the study on class $\mathrm{V}$ students in Cluster VI Abang District Karangasem regency showed that (1) learning styles of students in Indonesian dominant of the students is a visual learning style, (2) the students' motivation in learning Indonesian at SDN 1 Pidipid in the category very high, SDN 1 Nawa Kerti at the high category, and SDN 1 Kesimpar are in enough categories, (3) factors affecting the trend of student learning styles namely internal and external factors, and (4) factors that influence the motivation to learn is internal factor in the form of physical and psychological. While external factors such as social and non-social.
\end{abstract}

Keywords: learning styles, motivation to learn, learning Indonesian

\begin{abstract}
Abstrak: Penelitian ini bertujuan untuk mendeskripsikan motivasi dan gaya belajar siswa di Sekolah Dasar. Jenis penelitian ini adalah penelitian deskriptif. Sampel penelitiannya yakni siswa kelas V SD di Gugus VI Kecamatan Abang Kabupaten Karangasem tahun pelajaran 2015/2016 yakni SDN 1 Pidpid, SDN 1 Nawa Kerti, dan SDN 1 Kesimpar yang berjumlah 51 orang. Data dikumpulkan dengan menggunakan kuesioner, observasi, wawancara dan dokumentasi. Data yang dikumpulkan dianalisis menggunakan analisis deskriptif. Hasil penelitian menunjukkan bahwa (1) gaya belajar siswa dalam pembelajaran di Sekolah Dasar yang dominan dilakukan siswa adalah gaya belajar visual, (2) motivasi siswa dalam pembelajaran di SDN 1 Pidipid berada pada kategori sangat tinggi, SDN 1 Nawa Kerti berada pada kategori tinggi, dan SDN 1 Kesimpar berada pada kategori cukup, (3) faktor yang mempengaruhi kecendrungan gaya belajar siswa yaitu faktor internal dan eksternal, dan (4) faktor yang mempengaruhi motivasi dalam belajar yaitu faktor internal yang berupa fisik dan psikologis. Sedangkan faktor eksternal yang berupa non-sosial dan sosial.
\end{abstract}

Kata-kata kunci: gaya belajar, motivasi belajar, pembelajaran Bahasa Indonesia

Bahasa Indonesia adalah pengertian sosial dan bukan pengertian linguistik/kebahasaan atau metaforis (Daniel, 1996:3-5). Pengertian bahasa menekankan bahasa sebagai sarana berkomunikasi dan berpikir, dan sarana pemersatu Bahasa Indonesia. Pengertian bahasa sebagai sarana ini memastikan bahwa fungsi, tujuan, dan pembelajaran Bahasa Indonesia, yakni memperoleh dan mencapai keterampilan Bahasa Indonesia untuk berbagai keperluan berkomunikasi. Pada hakikatnya belajar bahasa adalah belajar berkomunikasi. Oleh karena itu pembelajaran Bahasa Indonesia diarahkan untuk meningkatkan kemampuan siswa dalam berkomunikasi dengan Bahasa Indonesia baik secara lisan maupun tertulis. Menurut Badan Standar Nasional 
Pendidikan (dalam Susanto, 2013:245), yang menguraikan standar isi Bahasa Indonesia sebaga berikut: "pembelajaran Bahasa Indonesia diarahkan untuk berkomunikasi dalam Bahasa Indonesia dengan baik dan benar, baik secara lisan maupun tulis, serta menumbuhkan apresiasi terhadap hasil karya kesusastraan manusia Indonesia". Hal ini didukung oleh Susanto (2013:245) yang mengemukakan bahwa "Tujuan pembelajaran Bahasa Indonesia di SD antara lain bertujuan agar siswa mampu menikmati dan memanfaatkan karya sastra untuk mengembangkan kepribadian, memperluas wawasan kehidupan, serta meningkatkan pengetahuan dan kemampuan berbahasa".

Pembelajaran Bahasa Indonesia di sekolah diharapkan dapat membantu siswa mengenal dirinya, budayanya dan budaya orang lain, mengemukakan gagasan dan perasaan, berprestasi dalam masyarakat yang menemukan serta menggunakan kemampuan analisis dan imajinatif yang ada dalam dirinya. Salah satu ketrampilan yang diharapkan dimiliki oleh siswa dari sekolah dasar ini adalah ketrampilan berbahasa yang baik karena bahasa merupakan modal terpenting bagi manusia. Dalam pembelajaran Bahasa Indonesia, ada empat ketrampilan yang harus dimiliki oleh siswa, keterampilan ini antara lain: mendengarkan, berbicara, membaca, dan menulis. Keempat aspek bahasa ini saling terkait antara satu dengan yang lainnya. Bagaimana seorang anak akan bisa menceritakan sesuatu setelah ia membaca ataupun setelah ia mendengarkan. Begitupun dengan menulis. Menulis tidak lepas dari kemampuan menyimak, membaca dan berbicara anak, sehingga keempat aspek ini harus senantiasa diperhatikan untuk kempuan siswa.

Saat ini, pembelajaran Bahasa Indonesia merupakan salah satu materi pembelajaran yang sangat penting di sekolah. Mata pelajaran ini bertujuan agar siswa mampu menguasai kemampuan berbahasa dan mampu mengaplikasikannya dalam kekidupan sehari-hari. Namun demikian ternyata sebagian siswa SD merasa Bahasa Indonesia lebih formal dan belakangan ini pembelajaran Bahasa Indonesia sudah menjadi momok bagi siswa. hal ini terlihat dari guru kurang mampu menyusun sumber belajar bagi siswa, memilih pendekatan dan metode yang sesuai dengan karakter siswa, serta memilih media yang tepat sebagai alat bantu dalam pembelajaran Bahasa Indonesia pada konsep tertentu dan di dalam pembelajaran guru kurang memperhatikan karakteristik dari siswanya di dalam belajar.

Hal ini dibuktikan dari hasil observasi yang dilakukan pada siswa kelas V SD Gugus VI Kecamatan Abang Kabupaten Karangasem pada hari Senin, 11 Januari 2016, di kelas saat pembelajaran Bahasa Indonesia terlihat bahwa siswa kurang berminat terhadap pembelajaran Bahasa Indonesia ini ditunjukan oleh sikap mereka saat mereka menerima pembelajaran, siswa di kelas cenderung pasif (saat pelajaran berlangsung) seolah-olah belum siap menerima pelajaran, siswa tidak mau bertanya selama dalam proses pembelajaran, siswa belajar dengan cara yang monoton. Berdasarkan keadaan diatas akhirnya menyebabkan rendahnya motivas belajar Bahasa Indonesia.

Kenyataan di atas tentu saja sangat bertentangan dengan bagaimana seharusnya siswa tersebut belajar. Kegiatan belajar dilakukan oleh siswa, dan melalui kegiatan itu akan ada perubahan prilakunya, sementara kegiatan pembelajaran dilakukan oleh guru untuk memfasilitasi proses belajar, kedua peranan itu tidak akan terlepas dari situasi saling memperbaiki dalam pola hubungan antara dua subjek.

Sadirman (2014:20) mendefinisikan "belajar merupakan perubahan tingkah laku atau penampilan, dengan serangkaian kegiatan misalnya dengan membaca, mengamati, mendengarkan meniru dan lain sebagiannya. Belajar merupakan usaha yang dilakukan oleh seseorang melalui interaksi dengan lingkungannya untuk merubah prilakunya. Dengan demikian, hasil dari kegiatan belajar adalah perubahan prilaku yang relatif permanen pada diri seorang yang melakukan kegiatan belajar, tentunya perubahan yang diharapkan adalah perubahan yang positif. Kegiatan belajar seringkali dikaitkan dengan kegiatan mengajar, begitu eratnya sehingga kegiatan belajar mengajar sulit dipisahkan. 
"Tujuan belajar yang utama ialah bahwa apa yang diajari itu berguna di kemudian hari, yakni membantu kita untuk belajar terus dengan cara yang lebih mudah", (Nasution, 2005:3). Tujuan pembelajaran bukan hanya penguasaan prinsip-prinsip yang fundamental, melainkan juga mengembangkan sikap yang positif terhadap belajar, penelitian, dan penguatan serta pemecahan masalah atas kemampuan sendiri.

Salah satu faktor belajar yang berpengaruh besar dalam pencapaian prestasi belajar adalah gaya belajar dan motivasi Secara teori, ada dua kategori tentang bagaimana individu belajar. Pertama, adalah cara individu dapat menyerap informasi dengan mudah, konsep ini disebut modalitas belajar. Kedua adalah bagaimana cara individu mengatur dan mengelola informasi tersebut, konsep ini disebut dominasi otak. Sementara gaya belajar merupakan suatu kombinasi dari bagaimana individu menyerap, mengatur, dan mengelola informasi. Gaya belajar menjadi bagian penting yang tidak terpisahkan dalam pembelajaran Bahasa Indonesia. Karena dalam proses pembelajaran Bahasa Indonesia, seorang membutuhkan suatu cara yang dianggapnya cocok atau nyaman dengan apa yang dijalaninya selama proses belajar tersebut. Kenyamanan dalam belajar tersebut merupakan gaya belajar yang dianggap cocok oleh si pelajar. Gaya belajar adalah kunci untuk mengembangkan kinerja dalam pekerjaan, di sekolah, dan dalam studi-studi antar pribadi.

Dalam proses pembelajaran agar materi yang disampaikan khususnya materi pembelajaran Bahasa Indonesia dapat dipahami sepenuhnya oleh siswa maka seorang guru harus memperhatikan gaya belajar atau "learning style" siswa, yaitu cara ia bereaksi dan menggunakanm perangsang-perangsang yang diterimanya dalam proses belajar. "Gaya belajar adalah cara yang konstan yang dilakukan oleh seorang murid dalam menangkap stimulus atau informasi, cara mengingat, berpikir, dan memecahkan soal", (Nasution, 2005:94). Gaya belajar ini sangat berkaitan erat dengan pribadi seseorang, yang tentu dipengaruhi oleh pendidikan dan riwayat perkembangaannya. Guru merupakan faktor penting yang besar pengaruhnya terhadap proses dan hasil belajar bahkan sangat menentukan berhasil tidaknya peserta didik dalam belajar.

Banyak faktor yang mempengaruhi proses belajar siswa. Salah satu faktor yang mempengaruhi adalah faktor dari dalam atau faktor psikologis. Sardiman A.M (2007:55) menyatakan bahwa salah satu faktor psikologis yang mempengaruhi belajar adalah faktor motivasi. Motivasi merupakan faktor psikologis dalam belajar yang sangat penting. Sardiman A.M (2007: 40) juga mengemukakan bahwa "motivasi belajar adalah keinginan atau dorongan untuk belajar. Motivasi dalam hal ini meliputi dua hal yaitu mengetahui apa yang akan dipelajari dan memahami mengapa hal tersebut patut dipelajari". Dengan demikian tanpa adanya motivasi belajar pada diri siswa maka kegiatan belajar akan sulit berhasil. Berdasarkan latar belakang tersebut untuk mengetahui gaya belajar dan untuk mengetahui motivasi belajar dalam pembelajaran bahasa Indonesia.

Menurut Husdarta dan Yudha, 2010:23), Bobbi DePorter dan Mike Hernacki (dalam Sagitasari, 2010), bahwa gaya belajar adalah cara yang cenderung dipilih siswa untuk bereaksi dan menggunakan dalam menangkap stimulus atau informasi, cara mengingat, berpikir, dan memecahkan soal dan kemudian mengatur serta mengolah informasi pada proses belajar.

Menurut Sardiman (2014:73), Menurut Mc. Donald (dalam Sardiman, 2014:73-74), Uno (2015:3), Koeswara 1989 (dalam Dimyati dan Mudjiono, 2015:80), bahwa motivasi adalah keseluruhan daya untuk menggerakkan diri siswa yang mengakibatkan kegiatan belajar yang menjalani kelangsungan dari kegiatan belajar dan memberikan arah pada kegiatan belajar sehingga tujuan yang diinginkan oleh subjek belajar itu bisa tercapai. Dalam belajar, prestasi siswa akan lebih baik jika siswa mempunyai dorongan motivasi orang untuk berhasil jauh lebih besar dalam diri siswa tersebut. 


\section{METODE}

Penelitian ini dilakukan adalah jenis penelitian deskriptif. Penelitian deskriptif ditunjukkan untuk mendeskripsikan suatu keadaan atau fenomena-fenomena apa adanya pada saat penelitian dilakukan. Penelitian deskriptif bisa mendeskripsikan suatu keadaan saja, tetapi bisa juga mendeskrpsikan keadaan dalam tahapantahapan perkembangan, (Agung, 2014:26). Penelitian ini dibantu dengan metode analisis data kualitatif. Jadi penelitian ini merupakan penelitian deskriptif dengan metode analisis data kualitatif.

Metode analisis deskriptif kualitatif yaitu suatu cara analisis/pengolahan data dengan jalan menyusun secara sistematis dalam bentuk kalimat/ kata-kata, katagorikatagori mengenai suatu objek (benda, gejala, variabl tertentu), sehingga akhirnya diperoleh kesimpulan umum", (Agung, 2014:110). Penelitian Deskriptif bisa mendeskripsikan suatu keadaan saja, tetapi bisa juga mendeskrpsikan keadaan dalam tahapan-tahapan perkembangan. Penelitian ini menggunakan teknik random sampling atau pengambilan anggota sampel dari populasi dilakukan secara sederhana untuk menetukkan sampel dari populasi yang ada. Cara atau teknik ini dapat dilakukan jika analisis penelitiannya cendrung deskriptif dan bersifat umum. Dari jumlah populasi yang digunakan dalam penelitian ini yakni di Gugus VI Kecamatan Abang Kabupaten Karangasem terdiri dari 7 Sekolah Dasar. Dalam penelitian ini terdiri dari tiga Sekolah Dasar yakni SDN 1 Pidpid, SDN 1 Nawa Kerti, dan SDN 1 Kesimpar.

Rancangan kegiatan penelitian ini mengikuti tahapan penelitian deskriptif kualitatif secara umum. Terdapat tiga tahapan meliputi tahap persiapan, tahap pelaksanaan dilapangan, dan tahap pasca lapangan. Pada tahap persiapan dilakukan yaitu, membuat rancangan penelitian, menetapkan lokasi penelitian, mengurus Izin, melaksanakan observasi awal, memilih dan menetapkan informan, menyiapkan instrumen penelitian, mempersiapkan diri sebagai peneliti. Pada tahap lapangan ini, dilakukan pengumpulan data menggunakan instrumen yang telah disiapkan sebelumnya. Pada tahap pasca lapangan kegiatan yang dilakukan yaitu menganalisis data yang diperoleh dari lapangan. Analisis data tersebut dilakukan secara deskriptif sesuai dengan data yang terkumpul dari instrumen yang digunakan. Data yang diperoleh dari obeservasi awal sampai akhir penelitian dianalisis, sehingga diperoleh suatu kesimpulan.

Metode pengumpulan data yang digunakan dalam penelitian ini adalah metode kuesioner, observasi, wawancara dan dokumentasi. Menurut Sugiyono (2012:223) menyatakan bahwa instrumen utama dalam penelitian deskriptif kualitatif adalah peneliti itu sendiri. Instrumen yang digunakan dalam penelitian ini lembar kuesioner, lembar observasi, pedoman wawancara dan dokumentasi. Adapun aspek yang diteliti pada lembar koesioner yakni gaya belajar visual, gaya belajar auditori, dan gaya belajar kinestetik. Indikator di pedoman wawancara yakni fisik, Pisikologis, non-sosial, dan sosial. Agar instrumen dapat layak digunakan dilakukanlah uji validitas instrumen oleh pakar dengan menggunakan formula Gregory.

Analisis data yang digunakan dalam penelitian ini yaitu analisis deskriftip kualitatif. Menurut pandangan Nasution (dalam Sugiyono, 2012:245), analisis data dalam penelitian kualitatif telah dimulai sejak merumuskan dan menjelaskan masalah, sebelum terjun kelapangan, dan berlangsung terus sampai penulisan hasil penelitian. Teknik analisis data dilakukan dengan tiga tahap yaitu analisis sebelum lapangan, analisis selama di lapangan yang terdiri dari reduksi data, penyajian data, dan vertifikasi data, serta analisis setelah pengumpulan data terakhir dengan cara data yang telah diperoleh selama masa pengumpulan data kemudian dianalisis dari awal hingga akhir untuk penyusunan laporan sehingga diperoleh kesimpulan akhir. Secara khusus, data yang terkumpul dicari rata-rata dan dianalisis secara deskriptif kualitatif. 


\section{HASIL DAN PEMBAHASAN}

\section{Hasil}

\begin{abstract}
Data hasil Penentuan Gaya Belajar Siswa dalam Pembelajaran Bahasa Indonesia diperoleh dari kuesioner yang terdiri dari tiga Aspek gaya belajar yaitu
\end{abstract}

(1) gaya belajar visual, (2) gaya belajar auditori, dan (3) gaya belajar kinestetik. Responden dari kuesioner ini berjumlah 51 siswa dari tiga SD di Gugus VI Kecamatan Abang. Berikut penjabaran hasil analisis penentuan gaya belajar siswa dalam pembelajaran Bahasa Indonesia yang dilakukan di SDN 1 Pidpid, SDN 1 Nawa Kerti, dan SDN 1 Kesimpar.

Tabel 1 Analisis Penentuan Gaya Belajar Siswa di SDN 1 Pidpid

\begin{tabular}{clcc}
\hline No. & Macam Gaya Belajar & Frekuensi & Persentase (\%) \\
\hline Visual & 4 & 25 \\
2 & Auditori & 4 & 25 \\
3 & Kinestetik & 8 & 50 \\
Total & 16 & 100 \\
\hline Berdasarkan hasil analisis pada & dengan sebaran frekuensi dan persentase \\
tabel 1, diperoleh bahwa gaya belajar siswa & masing-masing siswa yakni 4 orang (25\%) \\
dalam pembelajaran Bahasa Indonesia yang & di gaya belajar visual, 4 orang (25\%) di gaya \\
paling dominan dimiliki siswa di SDN 1 & belajar auditori dan 8 orang (50\%) di gaya \\
Pidpid adalah gaya belajar kinestetik, & belajar kinestetik.
\end{tabular}

Tabel 2 Analisis Penentuan Gaya Belajar Siswa di SDN 1 Nawa Kerti

\begin{tabular}{clcc}
\hline No. & Macam Gaya Belajar & Frekuensi & Persentase (\%) \\
\hline 1 & Visual & 17 & 63 \\
2 & Auditori & 5 & 19 \\
3 & Kinestetik & 5 & 19 \\
& Total & 27 & 100
\end{tabular}

Berdasarkan hasil analisis pada tabel

2, diperoleh bahwa gaya belajar siswa dalam pembelajaran Bahasa Indonesia yang paling dominan dimiliki siswa di SDN 1 Nawa kerti adalah gaya belajar visual, dengan sebaran frekuensi dan persentase masingmasing siswa yakni 17 orang (63\%) di gaya belajar visual, 5 orang (19\%) di gaya belajar auditori dan 5 orang (19\%) di gaya belajar kinestetik.

Tabel 3 Analisis Penentuan Gaya Belajar Siswa di SDN 1 Kesimpar

\begin{tabular}{|c|c|c|c|}
\hline No. & Macam Gaya Belajar & Frekuensi & Persentase $(\%)$ \\
\hline 1 & Visual & 4 & 50 \\
\hline 2 & Auditori & 1 & 12,5 \\
\hline 3 & Kinestetik & 3 & 37,5 \\
\hline & Total & 8 & 100 \\
\hline
\end{tabular}

Berdasarkan hasil analisis pada tabel 3, diperoleh bahwa gaya belajar siswa dalam pembelajaran Bahasa Indonesia yang paling dominan dimiliki siswa di SDN 1 Kesimpar adalah gaya belajar visual, dengan sebaran frekuensi dan persentase masing-masing siswa yakni 4 orang (50\%) di gaya belajar visual, 1 orang
$(12,5 \%)$ di gaya belajar auditori dan 3 orang $(37,5 \%)$ di gaya belajar kinestetik.

Berdasarkan hasil analisis pada tabel 4, diperoleh bahwa gaya belajar siswa dalam pembelajaran bahasa yang paling dominan dimiliki siswa di Gugus VI kecamatan Abang Kabupaten Karangasem adalah gaya belajar visual, dengan sebaran 
hasil rata-rata persentase dari ketiga gaya belajar di gugus VI kecamatan Abang Kabupaten Karangasem yaitu visual (46\%), auditori (18\%) dan kinestetik $(35,33 \%)$.

Temuan yang diperoleh dari wawancara yang dilakukan dengan guru kelas V di SDN 1 Pidpid. Dari gaya belajar kinestetik yang dominan digunakan di SDN 1 Pidpid, ada berbagai faktor yang mempengaruhi siswa tersebut cendrung menggunakan gaya belajarnya seperti faktor jasmaniah, psikologis, kelelahan, keluarga, dan sekolah. Terkait dengan faktor jasmaniah, ketika siswa mengalami sakit (jasmani atau rohani) otomatis kondisi siswa akan melemah dari keadaan ini sudah pasti akan mempengaruhi minat siswa untuk belajar Bahasa Indonesia. Disamping itu tidak terlepas dari faktor psikologis siswa juga sangat mempengaruhi kecndrungan gaya belajar kinestetik di SDN 1 Pipid. Menurut narasumber yaitu Ni Komang Sumiantini, S.Pd. menyatakan bahwa ketika faktor psikologis siswa baik maka gairah belajar siswapun meningkat dan sebaliknya ketika faktor psikologis siswa rendah (perhatian) maka gairah belajar cendrung akan menurun. Selanjutnya faktor keluarga dan sekolah memiliki peranan yang sangat besar untuk menunjang kemampuan siswa dalam proses pembelajaran serta mengasah gaya belajar yang cenderung digunakan siswa.

Temuan yang diperoleh dari wawancara yang dilakukan dengan guru kelas V di SDN 1 Nawa Kerti. Dari gaya belajar visual yang dominan digunakan di SDN 1 Nawa Kerti, ada berbagai faktor yang mempengaruhi siswa tersebut cendrung menggunakan gaya belajarnya seperti faktor jasmaniah, psikologis, kelelahan, keluarga, dan sekolah. Terkait dengan faktor jasmaniah, menurut narasumber I Made Ari Artana, S.Pd. SD. M.Pd. menyatakan bahwa ketika siswa sedang sakit otomatis kondisi siswa akan melemah dan konsentrasi siswa juga akan ikut berkurang, otomatis siswa tidak akan fokus dalam belajar.

Dari keadaan ini sudah pasti akan mempengaruhi gaya belajar yang di dominani siswa untuk belajar Bahasa Indonesia. Disamping itu tidak terlepas dari faktor psikologis siswa juga sangat mempengaruhi kecndrungan gaya belajar kinestetik di SDN 1 Nawa Kerti, yaitu ketika faktor psikologis siswa baik maka gairah belajar siswapun meningkat dan sebaliknya ketika faktor psikologis siswa rendah (perhatian) maka gairah belajar cendrung akan menurun. Selanjutnya faktor keluarga dan sekolah memiliki peranan yang sangat besar untuk menunjang kemampuan siswa dalam proses pembelajaran serta mengasah gaya belajar yang cenderung digunakan siswa.

Temuan yang diperoleh dari wawancara yang dilakukan dengan guru kelas V di SDN 1 Kesimpar. Dari gaya belajar visual yang dominan digunakan di SDN 1 Kesimpar, ada berbagai faktor yang mempengaruhi siswa tersebut cendrung menggunakan gaya belajarnya seperti faktor jasmaniah, psikologis, kelelahan, keluarga, dan sekolah. Terkait dengan faktor jasmaniah, menurut narasumber I Wayan Raka, S.Pd. menyatakan bahwa faktor sangat berpengaruh terhadap gaya belajar visual siswa. Jika kesehatan jasmani dan rohani siswa terganggu maka siswa akan sulit untuk menerima pembelajaran. Dan keadaan ini sudah pasti akan mempengaruhi gaya belajar yang domin dipilih siswa untuk belajar Bahasa Indonesia. Disamping itu tidak terlepas dari faktor psikologis siswa juga sangat mempengaruhi kecndrungan gaya belajar kinestetik di SDN 1 Pidpid, yaitu ketika faktor psikologis siswa baik maka gairah belajar siswapun meningkat dan sebaliknya ketika faktor psikologis siswa rendah (perhatian) maka gairah belajar cendrung akan menurun. Selanjutnya faktor keluarga dan sekolah memiliki peranan yang sangat besar untuk menunjang kemampuan siswa dalam proses pembelajaran serta mengasah gaya belajar yang cenderung digunakan siswa.

1) Deskripsi Data Motivasi Belajar Siswa di SDN 1 Pidpid

Data hasil motivasi belajar diperoleh dari kuesioner yang terdiri dari empat indikator dengan responden yang berjumlah 16 siswa di SDN 1 Pidpid. Hasil 
perhitungan motivasi belajar secara

4.1 berikut.

lengkap disajikan pada lampiran 1 dan

hasil analisisnya dapat dilihat pada Tabel

Tabel 4 Analisis Motivasi Belajar Kuesioner di SDN 1 Pidpid

\begin{tabular}{ccccc}
\hline Rata-rata & Interval Rata-rata & Kategori & Frekuensi & Persentase(\%) \\
\hline \multirow{2}{*}{124,8} & $\bar{X} \geq 120$ & Sangat Tinggi & 11 & 68,75 \\
& $100 \leq \bar{X}<120$ & Tinggi & 5 & 31,25 \\
& $80 \leq \bar{X}<100$ & Cukup & 0 & 0 \\
& $60 \leq \bar{X}<80$ & Rendah & 0 & 0 \\
& Sangat Rendah & 0 & 0
\end{tabular}

Berdasarkan hasil pada tabel di atas, diperoleh rata-rata skor $(\bar{X})$ motivasi belajar di SDN 1 Pidpid yakni 124,8 dan berada pada interval rata-rata $\bar{X} \geq 120$. Jadi motivasi belajar siswa kelas V di SDN 1 Pidpid termasuk pada kategori sangat tinggi. Adapun sebaran frekuensi dan persentase masing-masing siswa yakni 11 orang $(68,75 \%)$ dikategori sangat tinggi dan 5 orang $(31,25 \%)$ di kategori tinggi.
2) Deskripsi Data Motivasi Belajar di SDN 1 Nawa Kerti

Data hasil motivasi belajar diperoleh dari kuesioner yang terdiri dari empat indikator dengan responden yang berjumlah 27 siswa di SDN 1 Nawa Kerti. Hasil perhitungan motivasi belajar secara lengkap disajikan pada lampiran 1 dan hasil analisisnya dapat dilihat pada Tabel 4.2.

Tabel 5 Analisis Motivasi Belajar Kuesioner di SDN 1 Nawa Kerti

\begin{tabular}{ccccc}
\hline Rata-rata & Interval Rata-rata & Kategori & Frekuensi & Persentase(\%) \\
\hline \multirow{4}{*}{109,8} & $\bar{X} \geq 120$ & Sangat Tinggi & 3 & 11,11 \\
& $100 \leq \bar{X}<120$ & Tinggi & 15 & 55,6 \\
& $80 \leq \bar{X}<100$ & Cukup & 9 & 33,3 \\
& $60 \leq \bar{X}<80$ & Rendah & 0 & 0 \\
& Sangat Rendah & 0 & 0 \\
\hline
\end{tabular}

Berdasarkan hasil pada tabel di atas, diperoleh rata-rata skor $(\bar{X})$ motivasi belajar di SDN 1 Nawa Kerti yakni 109,8 dan berada pada interval rata-rata $\bar{X} \geq$ 100. Jadi motivasi belajar siswa kelas V di SDN 1 Nawa Kerti termasuk pada kategori tinggi. Adapun sebaran frekuensi dan persentase masing-masing siswa yakni 3 orang $(11,11 \%)$ dikategori sangat tinggi dan
15 orang $(56,6 \%)$ di kategori tinggi, dan 9 orang $(33,3 \%)$ dikategori cukup.

3) Deskripsi Data Motivasi Belajar di SDN 1 Kesimpar

Data hasil motivasi belajar diperoleh dari kuesioner yang terdiri dari empat indikator dengan responden yang berjumlah 8 siswa di SDN 1 Nawa Kerti. Hasil perhitungan motivasi belajar secara lengkap disajikan pada lampiran 1 dan hasil analisisnya dapat dilihat pada Tabel 4.3.

Tabel 6 Analisis Motivasi Belajar Kuesioner di SDN 1 Kesimpar

\begin{tabular}{ccccc}
\hline Rata-rata & Interval Rata-rata & Kategori & Frekuensi & Persentase(\%) \\
\hline & $\bar{X} \geq 120$ & Sangat Tinggi & 0 & 0 \\
88,125 & $100 \leq \bar{X}<120$ & Tinggi & 0 & 0 \\
& $80 \leq \bar{X}<100$ & Cukup & 4 & 50 \\
& $60 \leq \bar{X}<80$ & Rendah & 4 & 50 \\
& Sangat Rendah & 0 & 0 \\
\hline
\end{tabular}


Berdasarkan hasil pada tabel di atas, diperoleh rata-rata skor $(\bar{X})$ motivasi belajar di SDN 1 Kesimpar yakni 88,125 dan berada pada interval rata-rata $\bar{X} \geq 80$. Jadi motivasi belajar siswa kelas V di SDN 1 Kesimpar termasuk pada kategori cukup. Adapun sebaran frekuensi dan persentase masing-masing siswa yakni 4 orang (50\%) dikategori cukup dan 4 orang $(50 \%)$ di kategori rendah.

Kategori motivasi belajar yang diperoleh dari tiga SD di Gugus VI Kecamatan Abang Kabupaten Karangasem dan pada masing-masing SD yang diteliti selanjutnya dianalisis perindikator dari mativasi belajar yang terdiri dari empat bagian yaitu, (1) tekun mengerjakan tugas, (2) ulet menghadapi kesulitan, (3) cepat bosan dengan tugas-tugas yang rutin dan (4) senang mencari dan memecahkan masalah dan soal-soal.

Hasil penelitian mengenai faktorfaktor yang mempengaruhi motivasi belajar pada siswa kelas $\mathrm{V}$ didapatkan dari hasil observasi yang dilakukan di tiga SD yakni SDN 1 Pidpid, SDN 1 Nawa Kerti dan SDN 1 Kesimpar pada gugus VI kecamatan Abang Kabupaten Karangasem.

Hasil observasi masing-masing sub indikator. (1) Analisis indikator Fisik dengan sub indikator keadaan kesehatan. Data indikator fisik dengan sub indikator keadaan kesehatan dalam pembelajaran bahasa Indonesia dari rata-rata skor $(\bar{X})$ indikator fisik sub indikator keadaan kesehatan yakni 4,00 berada pada interval rata-rata $\bar{X} \geq 3,25$. Jadi termasuk dalam kategori sangat tinggi. Data indikator fisik dengan sub indikator panca indera rata-rata skor $(\bar{X})$ indikator fisik sub indikator panca indera yakni 3,7 berada pada interval ratarata $\bar{X} \geq 3,25$. Jadi termasuk dalam kategori sangat tinggi. (2) Analisis indikator Psikologis dengan sub indikator rasa ingin tahu. Data indikator psikologis dengan sub indikator rasa ingin tahu rata-rata skor $(\bar{X})$ indikator psikologis sub indikator rasa ingin tahu yakni 2,8 berada pada interval rata-rata $2,75 \leq \bar{X}<3,25$. Jadi termasuk dalam kategori tinggi. Analisis indikator Psikologis dengan sub indikator sifat kreatif. Data indikator psikologis dengan sub indikator sifat kreatif rata-rata skor $(\bar{X})$ indikator psikologis sub indikator sifat kreatif yakni 2,73 berada pada interval rata-rata $2,25 \leq$ $\bar{X}<2,75$. Jadi termasuk dalam kategori cukup. Analisis indikator Psikologis dengan sub indikator keinginan untuk mendapatkan simpati. rata-rata skor $(\bar{X})$ indikator psikologis sub indikator keinginan untuk mendapatkan simpati yakni 2,71 berada pada interval rata-rata $2,25 \leq \bar{X}<2,75$. Jadi termasuk dalam kategori cukup. Analisis indikator Psikologis dengan sub indikator keiningan untuk mendapatkan rasa aman. Data indikator psikologis dengan sub indikator keinginan untuk mendapatkan rasa aman rata-rata skor $(\bar{X})$ indikator psikologis sub indikator keinginan untuk mendapatkan rasa aman yakni 2,7 berada pada interval rata-rata $2,25 \leq \bar{X}<2,75$. Jadi termasuk dalam kategori cukup. (3) Analisis indikator non-sosial dengan sub indikator tempat. Data indikator non-sosial dengan sub indikator tempat rata-rata skor ( $\bar{X}$ ) indikator non-sosial sub indikator tempat yakni 3,3 berada pada interval ratarata $2,75 \leq \bar{X}<3,25$. Jadi termasuk dalam kategori tinggi. Analisis indikator non-sosial dengan sub indikator sarana dan prasarana. Data indikator non-sosial dengan sub indikator sarana dan prasarana rata-rata skor $(\bar{X})$ indikator non-sosial sub indikator sarana dan prasarana yakni 2,8 berada pada interval rata-rata $2,75 \leq \bar{X}<3,25$. Jadi termasuk dalam kategori tinggi. (4) Analisis indikator sosial dengan sub indikator interaksi guru antar siswa. Data indikator sosial dengan sub indikator interaksi guru antar siswa rata-rata skor $(\bar{X})$ indikator sosial sub indikator interaksi guru antar siswa yakni 2,9 berada pada interval ratarata $2,75 \leq \bar{X}<3,25$. Jadi termasuk dalam kategori tinggi. Analisis indikator sosial dengan sub indikator interaksi antar siswa. Data indikator sosial dengan sub indikator interaksi antar siswa rata-rata skor $(\bar{X})$ indikator sosial sub indikator interaksi antar siswa yakni 2,7 berada pada interval rata- 
rata $2,75 \leq \bar{X}<3,25$. Jadi termasuk dalam kategori tinggi.

\section{Pembahasan}

Gaya belajar siswa dalam pembelajaran bahasa Indonesia siswa kelas $\mathrm{V}$ pada tiga SD di gugus VI Kecamatan Abang Kabupaten karangasem memiliki masing-masing gaya belajar yang berbedabeda, Ada siswa yang memiliki gaya belajar visual, auditori, atau kinestetik. Perlu diketahui bahwa tidak ada siswa yang memiliki gaya belajar yang sama prcis, pasti ada perbedaan dari bagaimana siswa tersebut belajar Bahasa Indonesia. Hal tersebut sesuai dengan pernyataan menurut Nasution (2015) yakni tidak semua orang memiliki cara yang sama di dalam belajar, masing-masing menunjukan perbedaan, namun para peneliti dapat menggolonggolongkannya. Secara umum terlihat dari penjabaran data gaya belajar siswa dalam pembelajaran Bahasa Indonesia sebagian besar berada pada kategori baik dan sangat baik, hanya sebahian kecil siswa yang termasuk pada kategori cukup. Secara umum gaya belajar siswa dapat dilihat dari seberapa besar siswa tersebut menggunakan gaya belajarnya di dalam belajar. Hal ini sejalan dengan pendapat Nasution (2015) yakni gaya belajar siswa berkaitan erat dengan pribadi seseorang, yang tentu dipengaruhi dipengaruhi oleh pendidikan dan riwayat perkembangannya. Meskipun demikian, pada masing-masing aspek gaya belajar siswa yang terdiri aspek gaya belajar visual, gaya belajar auditori, dan kinestetik diperoleh hasil analisis yang berbeda. Bila dicamkan perbedaanperbedaan yang ada antar gaya belajar maka ada pegangan bagi guru untuk mengenal tipe-tipe siswa yang guru hadapi. Hal tersebut sejalan dengan pendapat Nasution (2015) yakni guru-guru harus mengetahui akan adanya tipe-tipe murid yang berbeda-beda tiap tipe murid berpikir dengan cara yang berlainan.

Berdasarkan hasil wawancara terkait faktor-faktor yang mempengaruhi kcndrungan gaya belajar siswa dalam pembelajaran Bahasa Indonesia, guru-guru kelas V pada tiga SD di gugus VI kecamatan Abang Kabupaten Karangasem selalu berusaha mengatasi permasalahan terkait kcndrungan gaya belajar siswa dengan caracara yang berpariasi pada masing-masing sekolah.

Berdasarkan hasil analisis data diketahui bahwa motivasi belajar siswa dalam pembelajaran bahasa Indonesia siswa kelas V di Gugus VI Kecamatan Abang Kabupaten Karangasem yakni di DSN 1 Pidpid, SDN 1 Nawa Kerti, dan SDN 1 Kesimpar diperoleh hasil yang berbeda pada tiga SD tersebut. Hasil analisisnya yakni SDN 1 Pidpid termasuk ke dalam kategori sangat tinggi. SDN 1 Nawa Kerti termasuk ke dalam kategori tinggi, SDN 1 Kesimpar termasuk ke dalam kategori cukup. Hal tersebut menunjukkan bahwa motivasi siswa dalam pembelajaran bahasa Indonesia siswa kelas V pada tiga SD di Gugus VI Kecamatan Abang Kabupaten Karangasem yang terilihat dari penjabaran data motivasi belajar sebagian besar berada pada kategori tinggi dan sangat tinggi, hanya sebagain kecil siswa termasuk pada kategori cukup. Meskipun demikian, pada masing-masing indikator motivasi belajar yang terdiri dari tekun mengerjakan tugas, ulet menghadapi kesulitan, cepat bosan dengan tugas-tugas yang rutin, dan senang mencari dan memecahkan masalah diperoleh hasil analisis yang berbeda.

Hal tersebut tidak lepas dari peran serta guru yang selalu berusaha membimbing dan mengarahkan siswanya agar bisa mengikuti pembelajaran bahasa Indonesia dengan baik sesuai perencanaan yang telah dirancang oleh guru. Dapat dimaknai bahwa masing-masing guru kelas V pada tiga SD di Gugus VI Kecamatan Abang Kabupaten Karangasem selalu berusaha memerankan diri sebagai penguat motivasi belajar dalam pembelajaran bahasa Indonesia.

Hal itu sejalan dengan pendapat Uno (2015) yang menjelaskan bahwa peranan motivasi penting dalam pembelajaran yaitu: (a) menentukan hal-hal yang dapat dijadikan penguat belajar apabila seseorang yang dihadapkan pada suatu masalah yang memerlukan pemecahan dan hanya dapat dipecahkan berkat bantuan hal-hal yang 
dapat dilaluinya, (b) memperjelas tujuan belajar yakni seseorang akan tetarik untuk belajar sesuatu apabila yang dipelajari itu sedikitnya sudah diketahui atau dinikmati oleh anak, (c) menentukan ketekunan belajar, bila anak sudah termotivasi, maka ia akan berusaha mempelajari sesuatu dengan baik dan tekun.

Berdasarkan hasil analisis data diketahui faktor-faktor yang mempengaruhi motivasi belajar siswa kelas V SD Gugus VI Kecamatan Abang Kabupaten Karangasem diperoleh hasil analisis yang berbeda pada setiap indikator. Data hasil analisis indikator fisik ada dua sub indikator keadaan kesehatan, diperoleh dari hasil observasi siswa kelas V pada tiga SD Gugus VI Kecamatan Abang Kabupaten Karangasem menunjukkan keadaasn kesehatannya sangat baik, segenap badan beserta bagianbagiannya bebas dari penyakit. Namun tidak semua siswa yang memiliki keadaan kesehatan yang sangat baik ada beberapa siswa yang sakit-sakitan tapi masih bisa mengikuti pembelajaran seperti biasa. Pada sub indikator panca indra, diperoleh dari hasil observasi siswa kelas V pada tiga SD Gugus VI Kecamatan Abang Kabupaten Karangasem menunjukkan panca indra siswa sangat sehat.

Pada indikator psikologis sub indikator rasa ingin tahu, diperoleh dari hasil observasi siswa kelas V pada tiga SD Gugus VI Kecamatan Abang Kabupaten Karangasem menunjukkan rasa ingin tahunya tinggi dalam mengikuti proses pembelajaran terutama dalam pembelajaran bahasa Indonesia. Dilihat dari tidak ada rasa bosan untuk belajar, siswa mengamati halhal yang baru, siswa sangat serius dalam belajar, aktif dalam belajar.

Pada indikator psikologis sub indikator sifat kreatif, diperoleh dari hasil observasi siswa kelas V pada tiga SD Gugus VI Kecamatan Abang Kabupaten Karangasem menunjukkan sifat kreatif yang cukup baik.

Pada indikator psikologis sub indikator keinginan untuk mendapatkan simpati, diperoleh dari hasil observasi siswa kelas V pada tiga SD Gugus VI Kecamatan Abang Kabupaten Karangasem menunjukkan keinginan untuk mendapatkan simpati cukup baik.

Pada indikator psikologis sub indikator keinginan untuk mendapatkan rasa aman, diperoleh dari hasil observasi,siswa kelas V pada tiga SD Gugus VI Kecamatan Abang Kabupaten Karangasem menunjukkan keinginan untuk mendapatkan rasa aman cukup baik. dilihat dari siswanya yang rajin, pintar, tidak suka mencontek, tidak nakal.

Pada indikator non-sosial sub indikator tempat, diperoleh dari hasil observasi, siswa kelas $\mathrm{V}$ pada tiga SD Gugus VI Kecamatan Abang Kabupaten Karangasem menunjukkan tempatnya sangat baik dan nyaman untuk proses pembelajaran, dilihat dari halamannya sangat bersih, nyaman, asri, dan sejuk.

Pada indikator non-sosial sub indikator sarana dan prasarana, diperoleh dari hasil observasi siswa kelas $\mathrm{V}$ pada tiga SD Gugus VI Kecamatan Abang Kabupaten Karangasem menunjukkan sarana dan prasarananya cukup mendukung untuk proses belajar mengajar. Maka dari itu guru tidak kesusahan mencari sarana dan prasaran untuk dipakai proses belajar mengajar dan proses pembelajaran berjalan dengan baik.

Pada indikator sosial sub indikator interaksi guru antar siswa, diperoleh dari hasil observasi siswa kelas V pada tiga SD Gugus VI Kecamatan Abang Kabupaten Karangasem menunjukkan interaksi guru antar siswa cukup baik.

Pada indikator sosial sub indikator interaksi antar siswa, diperoleh dari hasil observasi menunjukkan interaksi antar siswa yang baik, karena terjalin hubungan yang akrab antara siswa dan tidak ada yang bergaul secara berkelompok. Dengan adanya interaksi antar siswa dalam sebuah pembelajaran, hal ini membuat siswa mempunyai tingkat sosialisasi yang tinggi dan solidaritas antar siswa menjadi lebih baik.

\section{SIMPULAN}

Gaya belajar siswa dalam pembelajaran Bahasa Indonesia yang paling dominan dimiliki siswa di SDN 1 pidpid adalah gaya belajar kinestetik dan, di SDN 1 
Nawa Kerti adalah gaya belajar visual, di SDN 1 Kesimpar adalah gaya belajar visual.

Faktor-faktor yang mempengaruhi kendrungan gaya belajar siswa di kelas $\mathrm{V}$ di gugus VI Kecamatan Abang Kabupaten Karangasem ada berbagai faktor yang mempengaruhi siswa tersebut cendrung menggunakan gaya belajarnya seperti faktor jasmaniah, psikologis, kelelahan, keluarga, dan sekolah. Adapun solusi yang diberikan untuk mengatasi permasalahan tersebut yaitu dengan cara-cara yang berpariasi pada masing-masing sekolah.

$$
\text { Motivasi belajar dalam }
$$

pembelajaran bahasa Indonesia siswa SD di

Gugus VI Kecamatan Abang Kabupaten Karangasem mendapatkan hasil yang tinggi. Faktor-faktor yang mempengaruhi motivasi belajar antara lain (1) faktor internal dan (2) faktor eksternal.

\section{DAFTAR RUJUKAN}

Agung, A. A. G. 2014. Metodologi Penelitian Pendidikan. Yogyakarta: Aditya Media Publising.

Daniel, Jos. 1996. Pedoman Kegiatan Belajar Mengajar Bahasa Indonesia. Jakarta: Gramedia Widiasarana.

Dibia, Ketut, dkk. 2007. Pendidikan Bahasa Indonesia 2. Singaraja: Universitas Pendidikan Ganesha.

Dimyati dan Mudjiono. 2015. Belajar dan Pembelajaran. Jakarta: Rineka Cipta.

Husdarta dan Yudha. 2010. Belajar dan Pembelajaran. Bandung: Alfabeta.

Nasution. 2005. Berbagai Pendekatan dalam Proses Belajar dan Mengajar. Jakarta: PT Bumi Aksara.

Nihayah, Fita. 2011. Profil Gaya Belajar (Learning Style) dan IPK Mahasiswa Jurusan Biologi FMIPA UNNES. Skripsi Tidak Diterbitkan. Jurusan Biologi Fakultas Matematika dan Ilmu Pengetahuan Alam Universitas Negeri Semarang.

Sadirman. 2014. Interaksi dan Motivasi Belajar Mengajar. Jakarta: PT Rajagrafindo Prrsada.
Sugiyono.2012. Metode Penelitian Pendidikan Pendekatan Kualitatif, Kualitatif dan $R \& D$. Bandung: Alfabet.

Susanto, Ahmad. 2013. Teori Belajar dan Pembelajaran di Sekolah Dasar. Jakarta: Prenadamedia Group.

Uno, Hamzah, 2015. Teori Motivasi dan Pengukurannya. Jakarta: Bumi Aksara. 